\title{
Energy solidarity in the European Union in the context of the particular interests of the Member States
}

ABSTRACT: The article presents the question of solidarity in relation to the energy policy of the European Union. This topic seems particularly important in the context of the crisis of the European integration process, which includes, in particular, economic problems, the migration crisis and the withdrawal of the United Kingdom from the European Union (Brexit). The issue of solidarity was analyzed from the legal and formal, institutional, and functional and relational points of view. The aim of the article is to show to what extent the theoretical assumptions, resulting from the provisions of European law on the solidarity, correspond with the actions of the Member States in the energy sector. The practice of the integration process indicates that the particular national economic interests in the energy sector are more important for the Member States than working towards European solidarity. Meanwhile, without a sense of responsibility for the pan-European interest, it is not possible to effectively implement the EU's energy policy. The European Commission - as the guardian of the treaties - confronts the Member States with ambitious challenges to be undertaken "in the spirit of solidarity". In the verbal sphere, this is supported by by capitals of the individual countries, but in practice, the actions taken divide the Member States into opposing camps instead of building a sense of the European energy community. This applies in particular to such issues as: the management of the energy union, investments in the gas sector (e.g. Nord Stream I and Nord Stream II), and the position towards third countries - suppliers of energy raw materials to the EU (in particular towards the Russian Federation). Different views on the above problems make it extremely difficult for Member States to take action "in the spirit of energy solidarity". Thus, the energy problem becomes another reason for the weakening of European unity.

KEYWORDS: energy solidarity, energy policy, energy security, the European Union, European integration

\footnotetext{
${ }^{1}$ The Institute of Political Science, The University of Warsaw, Warsaw; e-mail: k.tomaszewski3@uw.edu.pl
} 


\section{Introduction}

The energy policy is associated with the activity of the state in relation to the broadly understood energy sector. This approach, however, seems too narrow in the era of international economic integration and globalization. The states no longer play a key role in shaping economic relations. This role was taken over by international organizations that affect both the modern economy and trade relations between states.

This also means a change in the perception of causative agents in the energy industry. A great example to illustrate this thesis is certainly the European Union. It is an organization that affects all aspects of Member States' activities. This is particularly evident in the case of the economy, where Member States resigned from their individual competences in favor of transnational management and joint ventures within the EU (Du Castel 2014). The effects of this transfer of competences can be seen clearly on the example of monetary policy or the common commercial policy.

The presented paper discusses the EU energy policy. It belongs to the sphere of the so-called shared competences between the Union and the Member States (Article 4, point 2 of the Treaty on the Functioning of the EU, hereinafter referred to as TFEU). This means that both the EU and Member States can adopt legally binding acts in this area. Member States exercise their competences in those areas that have not been handed over to EU institutions. Moreover, as specified in the mentioned treaty, the Member States shall exercise their competence to the extent that the Union has not exercised its competence (Article 2, point 2, of the Treaty on the Functioning of the EU, hereinafter referred to as TFEU). In practice, this means that the guidelines, which should be implemented by the Member States for the effective achievement of the integration objectives, are adopted at the transnational level.

The aim of this article is to demonstrate the extent to which the theoretical aspects of EU law are reflected in the activities of the Member States. Are they functioning "in the spirit of solidarity", which is one of the Union's most fundamental values, or are they guided by particular interests, which are primarily the protection of national interest and efforts aimed at ensuring domestic energy security? Can the actions of Member States in the framework of energy policy be perceived from the perspective of paradigms of the theory of realism (Donnelly 2000; Waltz 2000) or are they closer to the theory of intergovernmental liberalism (Moravcsik 1993)?

The main hypothesis of the presented article is that Member States do not act in solidarity with regard to energy policy problems. The dominance of vested interests is a key paradigm behind the Member States actions in this field. The lack of solidarity affects the effective implementation of the objectives of the energy and climate policy of the European Union.

Referring to the literature of the subject, it should be noted that this paper is inspired by works on EU law (Barcz 2017; Besson and Levrat 2012) and policies and economic problems of the European Union (Żukrowska 2008; Nowak-Far 2013; Jullien and Smith 2015; Du Castel 2014). The issue of international solidarity was analyzed in relation to the questions of developing policy or economic assistance (Muszyński 2015; Sangiovanni 2013) rather than the energy policy. 


\section{The issue of solidarity in the European Union - levels of scientific analysis}

The European Union is an organization of sovereign states based on a community of values. They were pointed out expressis verbis in Article 2 of the Treaty on European Union. It was emphasized that these values are common to the Member States in a society in which pluralism, non-discrimination, tolerance, justice, solidarity and equality between women and men prevail. In addition, Article 3 point 3 of the Treaty on European Union emphasizes that the EU (...) shall promote solidarity among Member States. To sum up, it can be concluded that solidarity is a fundamental value that is important in the context of the European integration process.

It is worth analyzing the practical application of this value to the energy policy. It seems essential to analyze it from the legal and formal, institutional, and functional and relational points of view. The first relates to the legislative framework, mainly the primary law. The second - institutional, includes the analysis of entities involved in the conceptualization and implementation of the energy policy. The third (functional-relational) is the most practical. The aim of the research in this area is to analyze the implications for energy policy that arise from the Treaty provisions relating to solidarity and interdependence between theory and practice.

When it comes to the analysis of EU law, it should be stated that the issue of solidarity has a solid formal and legal basis. Two dimensions of this issue are: a) the ideological dimension, as a self-contained value behind the actions of the member States of the EU (Article 2 of the TEU) and: b) the practical dimension, a specific mechanism of action, which, on the one hand, ensures the energy security, and, on the other hand, serve as a guideline for actions taken jointly by the Member States (e.g. TITLE VII SOLIDARITY CLAUSE, Article 222 of the TFEU).

The close relationship between the energy security and solidarity was emphasized in Article 122 of the TFEU stating that (...) the Council, on a proposal from the Commission, may decide, in a spirit of solidarity between Member States, upon the measures appropriate to the economic situation, in particular if severe difficulties arise in the supply of certain products, notably in the area of energy. Such provisions may be particularly important for those countries that are heavily dependent on energy supplies from a single source. In case of any difficulties in the supply of certain products, they could, in accordance with the Treaty, count on support from EU allies. Interpreting these provisions, however, one must remember about the infrastructure. Supplying energy is possible only when there are real possibilities of energy transmission to the country that needs it (Lucki 2010).

In addition, the concept of solidarity is mentioned in the provisions relating to the energy policy. According to the TITLE XXI of the TFEU: ENERGY: In the context of the establishment and functioning of the internal market and with regard for the need to preserve and improve the environment, Union policy on energy shall aim, in a spirit of solidarity between Member States, to: a) ensure the functioning of the energy market; b) ensure security of energy supply in the Union; c) promote energy efficiency and energy saving and the development of new and rene- 
wable forms of energy; and d) promote the interconnection of energy networks. (Article 194 of the TFEU). This means that the most important activities in the area of the energy sector should be made taking the concept of solidarity into account. It should be noted, however, that the treaties do not explain how to understand this concept. There is no formal definition of solidarity between states.

In the case of institutional dimension, it should be noted that solidarity is overshadowed by the principle of sincere cooperation, which is more pragmatic. According to Article 3 point 3 of the Treaty on European Union: Pursuant to the principle of sincere cooperation, the Union and the Member States shall, in full mutual respect, assist each other in carrying out tasks which flow from the Treaties. The Member States shall take any appropriate measure, general or particular, to ensure fulfilment of the obligations arising out of the Treaties or resulting from the acts of the institutions of the Union. The Member States shall facilitate the achievement of the Union's tasks and refrain from any measure which could jeopardize the attainment of the Union's objectives. Therefore, the principle of sincere cooperation shall ensure the effective implementation of the tasks arising from the pace of the European integration process. From the point of view of the European institutions, this means both the need to build good inter-institutional relations and positive relations with the Member States; from the point of view of the Member States - the need to cooperate in good faith with the EU institutions and other countries.

The European Commission is undoubtedly aware of the fact that the postulate of energy solidarity is not easy to implement. According to the Communication from the Commission "Energy 2020. A strategy for competitive, sustainable and secure energy", the obligation of solidarity among Member States will be null and void without a sufficient internal infrastructure and interconnectors across external borders and maritime areas. As a major energy importer, the EU is directly affected by the evolution of networks in neighboring countries. The construction of new interconnections at EU borders should receive the same attention and policies as intra-EU projects (European Commission 2010). The question of solidarity was systematically raised when discussing subsequent energy strategies.

It has been successfully incorporated into the discourse on the Energy Union by the European Commission. According to the Energy Union Package, Communication from the Commission: Our vision is of an Energy Union where Member States see that they depend on each other to deliver secure energy to their citizens, based on true solidarity and trust, and of an Energy Union that speaks with one voice in global affairs (European Commission 2015). In addition, the Commission pointed out that the key drivers of energy security are the completion of the internal energy market and more efficient energy consumption. This requires more transparency and more solidarity and trust between the participating countries. It was stressed that the EU's energy security is closely linked with its neighbors. Joint approaches in the field of energy can make all parts of the European Union stronger, for instance in case of supply shortages or disruptions. The spirit of solidarity in energy matters is explicitly mentioned in the Treaty and is at the heart of the Energy Union (European Commission 2015).

The practical reflection of this concept can be found in The Clean Energy for All Europeans Package, presented on November 30, 2016 (European Commission 2016a). The package covers 
several aspects: energy security, solidarity, and trust; the integrated European energy market; energy efficiency; reduction of emissions; stimulating research, innovation, and competitiveness. One of the key projects aimed at realizing these objectives is the Energy Union (European Commission 2017a).

Based on the European Commission initiatives, it can be stated that the Commission is willing to fulfill the provisions of the Treaty on energy solidarity. The Commission's vision of solidarity is primarily based on the development of effective mechanisms of interaction between Member States in case of a crisis in the supply of raw materials and expanding cross-border energy infrastructure within the EU.

The Commission's vision is positively received by other institutions as well as by the Member States. The effects of consultations are officially published, while the conclusions are included in strategic documents (Tomaszewski 2017a).

All proposals are discussed with the interested parties. Based on the analysis of formal and legal and institutional issues, the European Union seems to be guided by the noble idea of solidarity, which is consistently pursued by the discussed organization. However, taking the functional and relational dimension into account, the situation is much more complex. While the narrative in energy policy is consistent with the provisions of the European treaties, in practice the Member States are guided primarily by national interests. This is due to several prerequisites.

First of all, it is much easier to define a national interest than a more general "community interest", which is more difficult to operationalize in terms of political action. National interest can be defined in the time horizon, including the coming parliamentary elections or other important political events. Meanwhile, from the perspective of citizens of the Member States, the European Union appears as un objet politique non indentifié (i.e. an unidentified political object, which brings to mind the term: UFO), as Jacques Delors (Delors 1985) once pointed out.

Secondly, Member States have different visions of the future and importance of the energy sector in their national economies. They have their own national long-term energy development strategies. In terms of mega trends, these strategies are of course in line with EU objectives, but the way they are implemented depends on national conditions (Polish energy... 2016). The common denominator of many of the energy strategies of the Member States, is the realization of national interests and energy security of the state.

Thirdly, the economies of the Member States are diverse and it is difficult to match pan-European solutions to specific economic and geopolitical conditions (Klinger 2008). This concerns, in particular, the diversification of energy supplies, sources of energy production, and the characteristics of infrastructure connections (natural gas, oil, and electricity).

In summary, the practical implementation of the idea of European energy solidarity collides with individual expectations and particular interests of the Member States. Assuming that the idea of European solidarity is right, as it can strengthen the energy security in the EU, improve the functioning of the market (by increasing synergy between Member States), strengthen the EU's global negotiating position towards energy suppliers, in practice national arguments, which are contrary to the above, should be expected. As pointed out by A. Sangiovanni (Sangiovanni 2013), a practical approach to the "concept of solidarity" is a difficult challenge, because each 
country aims primarily at maximizing its own aspirations and achieving particular interests. Meanwhile, as emphasized by M. Muszyński (Muszyński 2015), the concept of European solidarity formulated in the Treaties has an element of sacrificing own interests for the benefit of others. The implementation of this idea in the energy policy seems to be extremely difficult or even impossible.

\section{The European (un)solidarity - the energy policy of the European Union}

Moving on the analysis of the issue of energy solidarity from the perspective of practice, it is necessary to indicate three basic areas that, even though they require cooperation of the Member States, have become a sphere of rivalry and disagreement: a) Energy Union, b) energy infrastructure, and c) the relationship between Member States and the Russian Federation as a supplier of natural gas and crude oil to the EU market.

Referring to the first problem, the Energy Union, it must be mentioned that the idea of this cooperation in the area of the energy sector was de facto developed by the Polish government in 2014 (Tusk 2014). One of the key elements of the Polish proposal was the idea of introducing joint negotiations with external suppliers on the purchase of natural gas by the entire European Union and establishing, at the EU level, a special agency for this purpose. This idea was intended, in particular, to weaken the position of the Russian Federation on the European gas market by building a common EU position with regard to the negotiated contracts. It was pointed out that gas prices in the EU countries that are strongly dependent on gas supplies from the Russian Federation (i.e. in Poland, Hungary, Lithuania, Latvia, and Estonia) are high because there are no alternative suppliers to the Russian monopolist Gazprom. This group of countries was therefore convinced that joint negotiations between Russia and the European Union would lower the prices. However, the so-called "old fifteen" countries, particularly France, the Netherlands, and Germany, with much better prices and alternative supply routes, took a different view. In addition to gas from the Russian Federation, Western Europe imported this raw material from Norway and North Africa. In addition, western EU countries have a number of LNG terminals, allowing importing gas from around the world (Hansen and Percebois 2015; Biały et al. 2018). The western European gas network, thanks to investments made over the years, is well developed. Particular attention should be paid to numerous system interconnections between individual countries. Further advantages include the liberalized gas markets and efficient gas trading.

The divergence of interests resulted primarily from the fact that the joint purchasing mechanism would lead to a situation in which Central and Eastern European countries would pay less for Russian gas, while recipients from Western Europe would pay more than before. 
The conclusions of the European Council of 19-20 March 2015 signaled that the chances of fulfilling ambitious postulates were low. The Council appealed to ensure full compliance with EU law of all agreements related to the buying of gas from external suppliers, notably by reinforcing the transparency of such agreements and compatibility with EU energy security provisions. In the case of contracts for the supply of gas, the need to ensure the confidentiality of commercially sensitive information was indicated (European Council 2015). These provisions maintained the status quo in relation to the issue of gas supplies to the EU Member States.

From the perspective of several years of discussions around the Energy Union, based on the analysis of European Commission documents, it can be seen that the concept of joint gas purchases is still far from being implemented. The Second Report on the State of the Energy Union published on February 1, 2017 does not discuss this issue (European Commission 2017). The explanatory memorandum to the Proposal for a Regulation of the European Parliament and of the Council concerning measures to safeguard the security of gas supply and repealing Regulation (EU) No 994/2010 (European Commission 2016), when referring to the principle of subsidiarity, recognizes that a certain level of coordination, transparency and cooperation is necessary as regards EU Member States' policies on security of supply, to ensure that the energy market functions properly and that there is a secure supply of gas within the European Union. In addition, it was underlined that action at the EU level could be also needed in certain situations (e.g. EU-wide and regional emergencies) where the security of supply in the EU cannot be sufficiently achieved by the Member States alone and can therefore, by reason of the scale or efforts of the action, be better achieved at EU level.

This, however, has not led to the implementation of the postulate of joint gas purchases. The Regulation (EU) 2017/1938 of the European Parliament and of the Council of October 25, 2017 adopted on the basis of the aforementioned EC proposal, although it discusses the question of ensuring solidarity in the gas sector (in particular - Article 13), does not address this issue. The Regulation defined rules regarding information exchange: in order to enable the competent authorities and the Commission to assess the situation in the field of security of gas supply at national, regional and EU, each company transmits gas to the interested competent authorities of the details of the gas supply contracts having a cross-border dimension, which expire more than a year... (Article 14, point 6A, The Regulation... 2017). However, it is underlined that the notification obligation shall not cover price information and shall not apply to the modifications related only to the gas price (article 14, paragraph $6 \mathrm{~b}$ ). This means that in addition to monitoring the contracts themselves (without taking into account price monitoring), no other measures are foreseen that could contribute to building a common system of negotiations and gas purchases for Member States.

Infrastructure is the second area of problems in the field of energy solidarity. Its development, especially in the trans-European dimension, is a key factor in raising the level of energy security for both the entire EU and individual Member States. According to the „Energy 2020. A strategy for competitive, sustainable and secure energy" proposed by the Commission, the new challenge is to provide the backbone for electricity and gas to flow where it is needed. Without a proper infrastructure across Europe, comparable to the means of transport of other strategic sectors 
such as telecommunications or transport, the market will however never deliver on its promises. Further efforts need to be made to upgrade energy infrastructure particularly in Member States that joined as of 2004 as well as in less developed regions. The Commission therefore calls for additional efforts in order to upgrade energy infrastructure, particularly in Member States that joined as of 2004 as well as in less developed regions. Investment of around EUR 1 trillion will be needed by 2020 to replace obsolete capacity, modernize and adapt infrastructures and cater to the increasing and changing demand for low carbon energy (European Commission 2010). It is worth noting, however, that the very development of infrastructure, especially in the context of adaptation to renewable energy sources, is just one of the problems.

A much more serious and controversial issue is the development of infrastructure for the supply of natural gas. In this respect, the expectations of Central and Eastern European countries, dependent on Russian gas supplies, and Western European countries, with alternative gas supply options, are different (Bachkatov 2012). An example of an investment that could be described as a project of European disagreement is undoubtedly the Nord Stream I gas pipeline, connecting Germany and the Russian Federation (Nagy et al. 2009). This gas pipeline, commissioned in 2011, strongly divided the Member States. Its construction has proved that the "energy solidarity" exist only theoretically. The controversies surrounding this project were discussed in numerous scientific papers (e.g. Rosicki G. and Rosicki R. 2012). The next controversial project is the Nord Stream II (two gas pipelines) (Nowak 2015; Gawlikowska-Fyk and Zaręba 2017).

Gas connections between Germany and the Russian Federation are, on the one hand, a perfect complement to gas supplies to the Western European market but, on the other hand, they reduce the importance of the existing transit countries of Russian gas: Poland, Ukraine, Belarus, and Slovakia. The latter countries are against these projects. They indicate a potential threat of Russian energy blackmail. The shareholders of the project from Western Europe, however, remain indifferent to these arguments, pointing out to anti-Russian sentiments in the former Eastern Bloc countries and their inability to adapt to modern economic challenges (Tomaszewski 2017).

The only real beneficiary of these conflicts is Russia, which, using particularisms among Member States from Western Europe and Central Eastern Europe, shows that the spirit of European solidarity formulated in the Treaties is severely neglected (Du Castel 2014; Hansen and Percebois 2015).

A counterbalance for Russian plans to dominate the EU gas supply market, promoted by the countries of Central and Eastern Europe, particularly Poland, is the North-South Corridor project. Its implementation will allow to reach Norwegian gas fields and will mark the beginning of the development of gas infrastructure on the European North-South axis. It would therefore be a new opening in relations with Russia and a strong argument in the context of negotiating new contracts for Russian gas supplies by countries with access to the North-South Corridor. The pattern seems obvious: the greater the diversification of supplies, the stronger the negotiating position of the Central and Eastern European countries in their relations with the Russian Federation.

The construction of energy infrastructure is a drastic example of the lack of solidarity between Member States. It proves that particular interests are much stronger than the arguments 
of the Member States. The gap between the expectations of Western Europe and the arguments of the Central and Eastern European countries confirms that energy security, at least in terms of infrastructure, is more likely to be achieved through bilateral agreements rather than on a Community level.

Another level of the analysis indicated above, on the basis of which the mechanisms of energy solidarity can be examined, is the relationship between individual Member States and third countries, i.e. energy suppliers. This applies particularly to the perception of relations with the Russian Federation, which is a key supplier of natural gas to the EU. The approach of Member States towards Russia can be explained by the dependence on Russian gas supplies (Marangé 2015) according to the scheme: the greater the share of Russian gas, the less firm attitude towards the Russian Federation regardless of Russian international behavior (e.g. non-respect of human rights, violations of democratic principles, violations of international law, e.g. aggression in neighboring countries - the conflict in Ukraine or actions aimed at destabilizing the political situation in Georgia).

When sanctions against Russia are discussed at the European Council, there is a clear split in the allies of the Russian Federation (it coincides with the level of dependence on gas supplies and is connected with trade exchange) and its opponents (countries that are not afraid of Russian energy blackmail). This situation means that European solidarity is only declared, but not implemented.

As indicated by A. Jafalian (Jafalian 2011), the Russian strategy divide et impera in the energy sector, based on bilateral gas contracts with the Member States and politically determined prices, makes the Member States unable to "speak with one voice" on Russian actions.

\section{Conclusions}

It is much easier to discuss the energy solidarity in the European Union than implementing practical project activities based on this value. Although defined in the relevant provisions of the European treaties, it is not clear how it should be implemented in practice.

From the formal and legal points of view, there is no doubt that "energy solidarity" is one of the foundations of the European integration process, as well as the basis of the energy policy of the European Union.

In the institutional aspect, it is also clear that the most important players are involved at the supranational level (European Commission) in order to flesh out the provisions of the treaties. This applies in particular to the promotion of issues related to climate protection, energy security, and the development of energy infrastructure (Żukrowska 2015).

In practice, the implementation of the postulate of energy solidarity in the European Union is very difficult due to the fact that the discussed concept de facto lacks semantic precision and due to the existence of divergent interests and expectations regarding the energy sector and energy policy, both in the national and international dimensions. 
Moving on to the conclusions de lege ferenda, the main hypothesis of this article needs to be addressed. The analysis of the EU energy policy indicates that the domination of national interests over the Community interest may constitute a main obstacle to the implementation of the objectives set out in Title XXI of the TFEU. Is there a way to overcome these weaknesses?

This depends on the vision of integration (Barcz 2015). The EU development scenarios up to 2025 proposed by the President of the European Commission - J.C. Juncker - envisage the strengthening or weakening of the existing links between Member States (European Commission 2017b). The "Doing much more together" scenario may allow the EU to implement effective energy policy and carry out ambitious projects. However, in the case of different scenarios, e.g. "Carrying on", "Those who want more do more," or "Nothing but the single market", the principle of energy solidarity is unlikely to be implemented. From the author's point of view, the perspective of choosing the first scenario seems unlikely.

\section{References}

BACHKatov, N. 2012. Diplomatic energy: issues and effects of energy diplomacy in the Russian Federation (L'énergie diplomate: Enjeux et effets de la diplomatie énergétique de la Fédération de Russie). Bruylant, Brussels, 266 pp. (in French).

BARCZ, J. 2015. On the model of the future EU: diverse integration or flexible integration? ( $W$ sprawie modelu przyszłej UE: integracja zróżnicowana czy integracja elastyczna?). Państwo i Prawo No. 5, pp. 19-35 (in Polish).

BARCZ, J. 2017. A new Treaty for the European Union? (Nowy Traktat dla Unii Europejskiej?). Państwo i Prawo No. 1, pp. 3-18 (in Polish).

BESSON, S. and LEVRAT, N. 2012. European Legal (Dis)orders. ((Dés)ordres juridiques européens). Schulthess-Bruylant-LGDJ, Brussels, 290 p. (in French).

Biaty et al. 2018 - Biaty, R., JANusz, P., Ruszel, M. and Szurlej, A. 2018. The significance of LNG supplies for balancing the natural gas demand in the EU countries (Znaczenie dostaw LNG w zbilansowaniu zapotrzebowania na gaz ziemny krajów UE). Zeszyty Naukowe Instytutu Gospodarki Surowcami Mineralnymi i Energia Polskiej Akademii Nauk No. 102, pp. 231-244 (in Polish).

DELORS, J. 1985. ICG: Speech by Jacques Delors (Luxembourg, 9 September). Bulletin of the European Communities. September 1985, No. 9.

DonNelly, J. 2000. Realism and International Relations. Cambridge University Press, Cambridge, 231 pp.

Du CASTEL, V. 2014. The security of energy supplies. Stakes and challenges for the European Union (La sécurité des approvisionnements énergétiques. Enjeux et défis pour l'Union européenne). L'Harmattan, Paris, 180 pp. (in French).

GAWLiKowsKA-FYK, A. and ZaręBA, S. 2017. Negotiations between the European Commission and Russia on Nord Stream 2 (Negocjacje Komisji Europejskiej z Rosja w sprawie Nord Stream 2). Bulletin of the Polish Institute of International Affairs (PISM Bulletin) No. 41 (981), 27.04.2017 (in Polish).

HANSEN, J.P. and PerceBoIs, J. 2015. Energy - economy and policies (Énergie - économie et politiques). De Boeck, Paris, 832 pp. (in French).

JAFALIAN, A. 2011. Russia, an energy power: from the use of a political weapon to a market-driven logic (La Russie, puissance énergétique: de l'arme politique aux logiques de marché). 166 p. (in French). 
Jullien, B. and Smith, A. 2015. The EU'S Government of Industries. Markets, institutions and politics. Routledge, London - New York, 266 pp.

KLINGER, T. 2008. Geopolitics of energy. Findings and issues (Géopolitique de l'énergie. Constats et enjeux). Studyrama, Paris, 126 p. (in French).

European Commission, 2010. Energy 2020. A strategy for competitive, sustainable and secure energy, COM (639) 2010

European Commission, 2015. A Framework Strategy for a Resilient Energy Union with a Forward-Looking Climate Change Policy, COM (80) 2015.

European Commission, 2016. Proposal for a Regulation of the European Parliament and of the Council concerning measures to safeguard the security of gas supply and repealing Regulation (EU) No 994/2010, COM (52) 2016.

European Commission, 2016a. Clean Energy For All Europeans, COM (860) 2016.

European Commission, 2017. Second Report on the State of the Energy Union, COM (53) 2017.

European Commission, 2017a. Commission Work Programme 2018 An agenda for a more united, stronger and more democratic Europe, COM (650) 2017.

European Commission, 2017b. White Paper on the future of Europe. Reflections and scenarios for the EU27 by 2025, COM (2025) 2017.

European Council, 2015. European Council meeting - Conclusions 19 and 20 March 2015, EUCO 11/15 [Online] https://www.consilium.europa.eu/media/21888/european-council-conclusions-19-20-march2015-en.pdf [Accessed: 2018-02-15].

ŁUCKI, Z. 2010. Instruments of energy policy (Instrumenty polityki energetycznej). Polityka Energetyczna - Energy Policy Journal Vol. 12, No. 1, pp. 5-20 (in Polish).

MARANGÉ, C. 2015. Do sanctions against Russia have a deterrent effect? (Les sanctions contre la Russie ont-elles un effect dissuasif?). Study of the IRSEM No. 37 (January 2015), pp. 8-14 (in French).

MoravcsiK, A. 1993. Preferences and Power in the European Community. A Liberal Intergovernmentalist Approach. Journal of Common Market Studies Vol. 31, No. 4, pp. 473-524.

MUSZYŃSKI, M. 2015. European solidarity - an obligation or act of political will? (Europejska solidarność - obowiązek czy akt woli politycznej?). Ośrodek Analiz Strategicznych, [Online] https://oaspl org/2015/09/07/europejska-solidarnosc-obowiazek-czy-akt-woli-politycznej [Accessed: 2018-02-02] (in Polish).

NAGY S. et al. 2009 - NAGY, S., RYCHLICKI, S. and SiEMEK, J. 2009. Actual situation and future evolution of gas relations between Russia, European Union and Poland (Stan obecny i ewolucja stosunków gazowych Rosji z Unia Europejska i Polska). Polityka Energetyczna - Energy Policy Journal Vol. 12, No. 2, pp. 393-421 (in Polish).

NowAK, Z. 2015. Gas Interests in Nord Stream 2 (Nord Stream-2 - ciag dalszy gry interesów). Bulletin of the Polish Institute of International Affairs (PISM Bulletin) No. 91 (823), 14.10.2015 (in Polish).

NowAK-FAR, A. 2013. Law and economy of the European Union's internal market (Prawo i ekonomia rynku wewnętrznego Unii Europejskiej). Poltext, Warsaw, 260 pp. (in Polish).

Polish power... 2016. Polish power sector riding on the wave of megatrends (Polska energetyka na fali mega trendów). Deloitte, Forum for Energy Analysis, Warsaw, 44 pp.

RosicKI, G. and RosicKI, R. 2012. The importance of the Nord Stream gas pipeline for Poland. (Znaczenie gazociagu Nord Stream dla Polski). Przegląd Bezpieczeństwa Wewnętrznego Vol. 4, No. 1, pp. 139-156 (in Polish).

Regulation... 2017. Regulation (EU) 2017/1938 of the European Parliament and of the Council of 25 October 2017 concerning measures to safeguard the security of gas supply and repealing Regulation (EU) No 994/2010, OJ L 280, 28.10.2017, pp. 1-56. 
SAngiovanni, A. 2013. Solidarity in the European Union. Oxford Journal of Legal Studies Vol. 33 (2), pp. 213-241.

TOMASZEWSKI, K. 2017. The influence of infrastructure investments in the gas sector on energy security in Central and Eastern Europe (Wplyw inwestycji infrastrukturalnych w sektorze gazowym na bezpieczeństwo energetyczne Europy Środkowo-Wschodniej). Środkowoeuropejskie Studia Polityczne No. 3, pp. 73-96 (in Polish).

TOMASZEWSKI, K. 2017a. Communicating reforms in energy policy of the EU - the example of Green and White Books (Komunikowanie reform w polityce energetycznej Unii Europejskiej na przykładzie zielonych i biatych ksiag). , e-Politikon” No. 21, pp. 78-101 (in Polish).

Tusk, D. 2014. Speech: The Energy Union is a test showing the real nature of the European Union, European Energy Security Strategy Conference, 21.05.2014 [Online] https://www.premier.gov.pl/en/news/ news/donald-tusk-in-brussels-on-europes-energy-security.html [Accessed: 2018-02-15].

TFEU - Treaty on the Functioning of the European Union (Consolidated version 2016) (Traktat o funkcjonowaniu Unii Europejskiej, wersja skonsolidowana) - OJ C 202 (2016).

TEU - Treaty on European union (Consolidated version 2016) (Traktat o funkcjonowaniu Unii Europejskiej, wersja skonsolidowana 2016) - OJ C 202 (2016).

WALTZ, K. 2000. Structural Realism After the Cold War. International Security Vol. 25, No. 1, pp. 5-41.

ŻUKROWSKA, K. et al. 2008. Economic crisis 2008+ test for the policy used. Counteraction methods and their effectiveness (Kryzys gospodarczy 2008+ test dla stosowanej polityki. Metody przeciwdziałania i ich skuteczność). SGH - Warsaw School of Economics, Warsaw, 662 pp. (in Polish).

ŻUKROWSKA, K. 2015. International security model in twenty first century: from theory to practice (Model bezpieczeństwa międzynarodowego XXI wieku. Od teorii do praktyk). Krakowskie Studia Międzynarodowe No. 1 (XII), pp. 15-39 (in Polish).

\section{Solidarność energetyczna Unii Europejskiej w kontekście partykularnych interesów państw członkowskich}

\section{Streszczenie}

Artykuł prezentuje problematykę solidarności w odniesieniu do polityki energetycznej Unii Europejskiej. Tematyka ta wydaje się szczególnie istotna w dobie kryzysu procesu integracji europejskiej, na który składają się w szczególności problemy gospodarcze, kryzys migracyjny oraz wystąpienie Wielkiej Brytanii z UE (tzw. Brexit). Zagadnienie solidarności zostało poddane analizie w trzech płaszczyznach badawczych: formalno-prawnej, instytucjonalnej oraz funkcjonalno-relacjonalnej. Celem artykułu jest wykazanie, w jakim stopniu założenia teorii, wynikające z zapisów prawa europejskiego w zakresie solidarności korespondują z rzeczywistymi działaniami państw w sektorze energetycznym. Praktyka procesu integracji wskazuje bowiem, że partykularne, narodowe interesy gospodarcze w sferze energii są bardziej istotne dla państw członkowskich, aniżeli wspólne działanie na rzecz europejskiej solidarności. Tymczasem, bez poczucia 
odpowiedzialności za interes ogólnoeuropejski nie jest możliwe efektywne realizowanie założeń polityki energetycznej UE. Komisja Europejska - jako strażniczka traktatów - stawia przed państwami członkowskimi ambitne wyzwania, które mają być podejmowane „w duchu solidarności”. W sferze werbalnej znajduje ona poparcie w stolicach poszczególnych krajów, jednak - w praktyce - podejmowane są działania, które zamiast budować poczucie europejskiej wspólnoty energetycznej, dzielą państwa członkowskie na przeciwstawne obozy. Dotyczy to zwłaszcza takich kwestii, jak: zarządzanie unią energetyczną, inwestycje infrastrukturalne w sektorze gazowym (np. Nord Stream I oraz Nord Stream II), stanowisko wobec państw trzecich - dostawców surowców energetycznych do UE (w szczególności wobec Federacji Rosyjskiej). Zróżnicowane spojrzenie na powyższe problemy powoduje, że państwom członkowskim niezwykle trudno jest podejmować działania „w duchu solidarności” energetycznej. Tym samym, problematyka energii staje się kolejną przesłanką do osłabienia jedności europejskiej.

SŁOWA KLUCZOWE: solidarność energetyczna, polityka energetyczna, bezpieczeństwo energetyczne, Unia Europejska, integracja europejska 
